\title{
PENILAIAN PORTOFOLIO DALAM LINGKUP PEMBELAJARAN BERBASIS KOMPETENSI
}

\author{
Realin Setiamihardja
}

\begin{abstract}
ABSTRAK
Penilaian portofolio merupakan metode penilaian berkesinambungan dengan berbagai kumpulan informasi atau dokumentasi hasil pekerjaan seseorangyang diambil selama proses pembelajaran dalam kurun waktu tertentu dan disimpan pada suatu bendel secara sistematis dan terorganisir.Penilaian ini dianggap sebagian peneliti pendidikan adalah penilaian alternatif di dunia modern dan jauh lebih reliable dan valid daripada penilaian baku.Model portofolio assessment cocok digunakan untuk mata pelajaran yang bersifat menuntut outputpembelajaran siswa dari segi pengetahuan, keterampilan dan sikap. Aspek yang diukur dalam penilaian portofolio adalah tiga domain perkembangan psikologi anak yaitu kognitif, afektif dan psikomotorik.Komponen penilaian portofolio meliputi: (1) catatan guru, (2) hasil pekerjaan peserta didik, dan (3) profil perkembangan peserta didik.Fungsi penilaian portofolio adalah sebagai alat untuk mengetahui kemajuan kompetensi yang telah dicapai peserta didik dan mendiagnosis kesulitan belajar peserta didik, memberikan umpan balik untuk kepentingan perbaikan dan penyempurnaan KBM.
\end{abstract}

\section{Kata Kunci: Penilaian, Portofolio, Pembelajaran, Kompetensi}

\section{A. PENDAHULUAN}

Kritik terhadap rendahnya mutu pendidikan di berbagai satuan pendidikan, semakin menajam. Semula tuduhannya dilontarkan terhadap guru yang kurang profesional, sekarang semakin menajam kepada hal-hal yang lebih khusus dari tugas guru, yaitu terhadap alat atau instrumen dan tidak reliable, aspek yang dinilai oleh guru. Evaluasi yang dilakukan oleh guru tidak valid dan tidak teliable, aspek yang dinilai oleh guru tidak lengkap, serta administrasi guru dalam bidang penilaian juga sering tidak lengkap.

Bukti atas hal itu, pernah ditemukan anak yang sudah pindah sekolah tiga bulan sebelum waktu kenaikan kelas, atau anak yang sudah keluar beberapa bulan sebelum kenaikan kelas, pada saat kenaikan kelas anak tersebut masih mempunyai nilai dari guru untuk dipertimbangkan. Akhirnya sampai pada suatu kesimpulan bahwa pendekatan penilaian yang digunakan saat ini sudah tidak cocok lagi dan harus diganti dengan pendekatan lain. 
Sebagai reaksi atas hal di atas, bersamaan dengan adanya pergantian kurikulum, diperkenalkan pula pendekatan baru dalam penilaian, yaitu penilaian berbasis portofolio (portofolio based assessment). Yaitu model penilaian yang diharapkan mampu mengungkap dan menilai peserta didik lebih akurat dan lebih lengkap didasarkan pada bukti (dokumen) yang dipunyai oleh masing-masing siswa.

\section{B. PEMBAHASAN}

\section{Pengertian Portofolio}

Secara etimologi, portofolio berasal dari dua kata, yaitu port (singkatan dari report) yang berarti laporan dan folio yang berarti penuh atau lengkap. Jadi portofolio berarti laporan lengkap segala aktivitas seseorang yang dilakukannya. Secara umum portofolio merupakan kumpulan dokumen seseorang , kelompok, lembaga, organisasi, perusahaan atau sejenisnya yang bertujuan untuk mendokumentasikan perkembangan suatu proses dalam mencapai tujuan yang telah ditetapkan.

Menurut Gronlund (1998:159) portofolio mencakup berbagai contoh pekerjaan siswa yang tergantung pada keluasan tujuan. Apa yang harus tersurat, tergantung pada subjek dan tujuan penggunaan portofolio. Contoh pekerjaan siswa ini memberikan dasar bagi pertimbangan kemajuan belajarnya dan dapat dikomunikasikan kepada siswa, orang tua serta pihak lain yang tertarik berkepentingan.

Portofolio dapat digunakan untuk mendokumentasikan perkembangan siswa. Karena menyadari proses belajar sangat penting untuk keberhasilan hidup, portofolio dapat digunakan oleh siswa untuk melihat kemajuan mereka sendiri terutama dalam hal perkembangan, sikap keterampilan dan ekspresinya terhadap sesuatu.

Contoh pekerjaan siswa ini memberikan dasar bagi pertimbangan bagi kemajuan belajarnya dan dapat dikomunikasikan dengan siswa, orang tua serta pihak lain yang berkepentingan. Sehingga portofolio dapat digunakan untuk mendokumentasikan perkembangan siswa dalam setiap kegiatan dan proses 
pembelajaran. Secara umum, dalam dunia pendidikan portofolio merupakan kumpulan hasil karya siswa atau catatan mengenai siswa yang didokumentasikan secara baik dan teratur. Portofolio dapat berbentuk tugas-tugas yang dikerjakan siswa, jawaban siswa atas pertanyaan guru, catatan hasil observasi guru, catatan hasil wawancara guru dengan siswa, laporan kegiatan siswa dan karangan atau jurnal yang dibuat siswa.

Portofolio adalah kumpulan hasil karya seorang siswa, sebagai hasil pelaksanaan tugas kinerja, yang ditentukan oleh guru atau oleh siswa bersama guru, sebagai bagian dari usaha mencapai tujuan belajar, atau mencapai kompetensi yang ditentukan dalam kurikulum.

Portofolio dalam arti ini, dapat digunakan sebagai instrumen penilaian atau salah satu komponen dari instrumen penilaian, untuk menilai kompetensi siswa, atau menilai hasil belajar siswa. Portofolio demikian disebut juga 'portofolio untuk penilaian' atau 'portofolio penilaian'. Penilaian portofolio merupakan satu metode penilaian berkesinambungan, dengan mengumpulkan informasi atau data secara sistematik atas hasil pekerjaan seseorang (Pomham, 198). Aspek yang diukur dalam penilaian portofolio adalah tiga domain perkembangan psikologi anak yaitu kognitif, afektif dan psikomotorik.

Budimansyah, Dasim (2002) menjelaskan tentang pengertian portofolio sebagai berikut. "Portofolio sebenarnya dapat diartikan sebagai suatu wujud benda fisik, sebagai suatu proses sosial pedagogis, maupun sebagai adjective”. Sebagai suatu wujud benda fisik portofolio itu adalah bundel, yakni kumpulan atau dokumentasi hasil pekerjaan peserta didik yang disimpan pada suatu bundel. Misalnya, hasil tes awal (pre-test), tugas-tugas, catatan anekdot, piagam penghargaan, keterangan melaksanakan tugas terstruktur, hasil tes akhir (posttest), dan sebagainya. Sebagai suatu proses pedagogis, portofolio adalah collection of larning experience yang terdapat di dalam pikiran peserta didik baik yang berwujud pengetahuan (kognitif), keterampilan (skill), maupun nilai dan sikap (afektif). Adapun sebagai suatu adjective portofolio sering kali disandingkan dengan konsep lain, misalnya dengan konsep pembelajaran dan penilaian. Jika disandingkan dengan konsep pembelajaran maka dikenal istilah 
pembelajaran berbasis portofolio (portofolio based learning), sedangkan jika disandingkan dengan konsep penilaian, maka dikenal istilah penilaian berbasis portofolio (portofolio based assessment).

Portofolio biasanya merupakan karya terpilih dari seorang siswa. Tetapi dapat juga berupa karya terpilih dari satu kelas secara keseluruhan yang bekerja secara kooperatif membuat kebijakan untuk memecahkan masalah. Istilah "karya terpilih” merupakan kata kunci dari portofolio. Maknanya adalah bahwa yang harus menjadi akumulasi dari segala sesuatu yang ditemukan para siswa dari topik mereka harus memuat bahan-bahan yang menggambarkan usaha terbaik siswa dalam mengerjakan tugas-tugas yang diberikan kepadanya, serta mencakup pertimbangan terbaiknya tentang bahan-bahan mana yang paling penting.Oleh karena itu portofolio bukanlah kumpulan bahan-bahan yang asal comot dari sanasini, tidak ada relevansinya satu sama lain, ataupun bahan yang tidak memperlihatkan signifikansi sama sekali.

Menurut Budimansyah, Dasim (2002), model penilaian berbasis portofolio mengacu pada sejumlah prinsip dasar penilaian. Prinsip-prinsip dasar penilaian dimaksud adalah penilaian proses dan hasil, penilaian berkala dan bersinambung, penilaian yang adil, dan penilaian implikasi sosial belajar. Sedangkan indikator penilaian portofolio, yaitu tes formatif dan sumatif, tugas-tugas terstruktur, catatan perilaku harian, laporan aktivitas di luar sekolah.

\section{Mengapa menggunakan penilaian portofolio?}

Dalam proses Kegiatan Belajar Mengajar (KBM), proses pengujian atau penilaian merupakan suatu komponen yang tidak kalah penting dibandingkan dengan proses lainnya. Penilaian atau pengujian atau sering disebut juga assessment memiliki banyak model, seperti penilaian berbasis kelas, benchmarking, dan portofolio.

Portofolio pada mulanya hanya sebagai wujud benda fisik, artinya sebagai kumpulan atau dokumentasi hasil pekerjaan peserta didik yang disimpan pada suatu bendel misalnya hasil tes awal, tugas-tugas catatan anekdot, piagam penghargaan dan hasil tes akhir. Sebagai proses sosial pedagogis, portofolio 
merupakan kumpulan dari pengalaman belajar (collectionoflearning experience) dan ini dapat berupa pengetahuan (cognitive), keterampilan (skill), nilai atau sikap (affective) yang terdapat dalam pikiran peserta didik (Budimansyah, Dasim: 2002). Lebih lanjut Budimansyah, Dasim menjelaskan bahwa portofolio sebagai konsep pembelajaran dan konsep penilaian, yang dikenal dengan istilah pembelajaran berbasis portofolio (portofolio based assessment).

Pembelajaran berbasis portofolio memposisikan siswa sebagai titik sentralnya (student oriented). Dalam proses pembelajaran siswa harus dimotivasi untuk mau dan mampu melakukan sesuatu untuk memperkaya pengalaman bekerjanya dengan lebih mengintensifkan interaksi dengan lingkungannya. Dengan interaksi ini diharapkan mampu membangun pemahaman terhadap dunia sekitar, kepercayaan diri dan kepribadian siswa yang paham akan keanekaragaman yang ada gilirannya dapat tumbuh sikap positif dan perilaku toleran terhadap kebinekaan dan perbedaan pola kehidupan.

Dengan demikian pembelajaran portofolio merupakan model pembelajaran partisipatorik, yaitu belajar sambil menjalankan (learning by doing) dengan proses sebagai berikut (1) mengidentifikasi masalah; (2) memilih masalah sebagai bahan kajian kelas; (3) mengumpulkan informasi masalah yang akan dikaji; (4) mengembangkan portofolio kelas; (5) menyajikan portofolio; dan (6) merefleksikan pengalaman belajar.

Model portofolio assessment cocok digunakan untuk mata pelajaran yang bersifat menuntut output pembelajaran siswa dari segi pengetahuan, keterampilan dan sikap. Penilaian ini berupa penilaian terhadap sekumpulan karya peserta didik yang tersusun secara sistematis dan terorganisir yang diambil selama proses pembelajaran dalam kurun waktu tertentu.

Menurut Suderajat dan Sumerna (Tsaur, Sufyan: 2009), alasan mengapa menggunakan penilaian portofolio karena:

a. Dapat menghargai proses pembelajaran hasil belajar siswa

b. Mendokumentasikan proses pembelajaran yang berlangsung

c. Memberi perhatian pada prestasi siswa yang memang memiliki prestasi

d. Bertukar informasi dengan orang tua /wali, peserta didik dan guru 
e. Meningkatkan efektivitas proses pengajaran

f. Dapat merefleksikan kesanggupan mengambil resiko dan melakukan eksperimen

g. Dapat membina dan mempercepat pertumbuhan konsep diri pada siswa

h. Siswa memandang lebih objektif dan terbuka dibandingkan dengan penilaian tradisional karena siswa menilai hasil kinerja sendiri

i. Membantu peserta didik dalam merumuskan tujuan

Menurut Djahiri, A.K (2001), dalam proses pembelajaran prinsip utamanya adalah proses keterlibatan seluruh/sebagian besar potensi diri siswa (fisik dan non fisik) dan kebermaknaannya bagi diri dan kehidupannya saat ini dan di masa yang akan datang (life skill). Dalam pembelajaran berbasis portofolio ada 7 prinsip, yaitu cooperative group learning, studet based, demokratismunanistik dan transparan, faktual based (materi belajar dikaitkan dengan kehidupan), multi dimensional, yakni multi domain, multi gatra, multi media/sumber dan multi penilaian., fungsi guru sebagai fasilitas dan tempat kelas, sekolah dan luar sekolah.

Sementara itu Budimansyah, Dasim (2002), secara garis besar menyatakan, bahwa prinsip pembelajaran portofolio pada intinya adalah:

a. Empat Pilar Pendidikan

Empat pilar pendidikan sebagai landasan model pembelajaran berbasis portofolio adalah learning to do, learning to know, learning to be and learning to live together, yang dicanangkan UNESCO. Hal ini mengandung arti bahwa dalam pembelajaran kita tidak boleh memperlakukan peserta didik seperti bak kosong yang selalu dijejali berbagai informasi melalui ceramah

b. Pandangan Konstruktivisme

Konstruktivisme mengajarkan tentang sifat dasar manusia belajar. Menurut konstruktivisme belajar adalah constructing understanding atau nowledge, dengan cara mencocokkan fenomena, ide atau aktivitas yang baru dengan pengetahuan yang telah ada dan percaya bahwa sudah dipelajari. Dalam hal ini kata kuncinya adalah construct. Konsekuensinya siswa dalam proses pembelajaran seharusnya bersungguh-sungguh membangun ini atau makna 
dalam sudut pandang pembelajaran bermakna bukan sekedar hafalan atau tiruan.

\section{c. Democratic Teaching}

Melalui kegiatan pembelajaran berbasis portofolio peserta didik dilatih dan dibiasakan untuk hidup berdemokrasi. Proses demokrasi dimulai dari perumusan permasalahan kelas sampai pada penyajian portofolio. Hal ini nampak pada aktivitas dan kreativitas siswa yang begitu bebas untuk mengekspresikan berbagai pengalaman belajarnya. Hal ini sudah barang tentu merupakan upaya positif dalam mewujudkan kehidupan demokrasi, termasuk di negara Indonesia.

d. Prinsip Belajar Siswa Aktif

Aktivitas siswa dalam proses pembelajaran dengan menggunakan model pembelajaran berbasis portofolio nampak sekali. Hal ini dapat dilihat dari tahap-tahap atau langkah-langkah kegiatan, dimana hampir semua langkah kegiatan melibatkan seluruh aktivitas siswa.

e. Kelompok Belajar Kooperatif

Proses pembelajaran dengan pendekatan berbasis portofolio secara jelas dan menerapkan sistem belajar kooperatif, yaitu proses pembelajaran yang berbasis kerja sama. Kerja sama antar siswa dan antar komponen-komponen lain di sekolah, termasuk kerja sama sekolah dengan orang tua siswa dan lembaga terkait.

f. Pembelajaran Partisipatrik

Proses pembelajaran dengan pendekatan berbasis portofolio juga menganut prinsip dasar pembelajaran partisipatorik, sebab melalui model ini siswa belajar sambil menjalankan (Learning by doing). Salah satu bentuk perjalanan hidup berdemokrasi. Sebab dalam tiap langkah dalam model ini memiliki makna yang ada hubungannya dengan praktek hidup berdemokrasi.

g. Reactive Teaching

Proses pembelajaran dengan pendekatan berbasis portofolio, guru perlu menciptakan strategi yang tepat agar siswa mempunyai motivasi belajar yang 
tinggi. Motivasi yang seperti itu akan dapat tercipta kalau guru dapat meyakinkan siswa akan kegunaan materi pelajaran bagi kehidupan nyata.

Demikian juga guru harus dapat menciptakan situasi sehingga materi pelajaran selalu menarik, tidak membosankan. Guru harus punya sensitivitas yang tinggi untuk segera mengetahui kegiatan pembelajaran sudah membosankan siswa. Jika hal ini terjadi, guru harus segera mencari cara untuk menanggulanginya. Inilah tipe guru yang kreatif itu. Ciri guru kreatif itu di antaranya adalah sebagai berikut: menjadikan siswa sebagai pusat kegiatan belajar, pembelajaran dimulai dengan hal-hal yang sudah diketahui dan dipahami siswa, selalu berupaya membangkitkan motivasi belajar siswa dengan membuat materi pelajaran sebagai sesuatu hal yang menarik da berguna bagi kehidupan siswa da segera mengenali materi atau metode pembelajaran yang membuat siswa bosan. Bila hal ini ditemui, ia segera menanggulanginya.

Penilaian portofolio merupakan penilaian berkelanjutan yang didasarkan pada kumpulan informasi yang menunjukkan perkembangan kemampuan peserta didik dalam satu periode tertentu. Informasi tersebut dapat berupa karya peserta didik dalam satu periode tertentu. Informasi tersebut dapat berupa karya peserta didik dari proses pembelajaran yang dianggap terbaik oleh peserta didik. Dalam penilaian portofolio mengandung hal-hal penting, yaitu pengumpulan (storing), pemilihan (sorting) dan penetapan (dating), dari suatu tugas (task) (Supranata dan Hatta, 2004).

Tujuan portofolio diterapkan berdasarkan apa yang harus dikerjakan dan siapa yang akan menggunakan jenis portofolio. Dalam penilaian di kelas, portofolio dapat digunakan untuk mencapai beberapa tujuan, antara lain:

a. Menghargai perkembangan yang dialami siswa

b. Mendokumentasikan proses pembelajaran yang berlangsung

c. Memberi perhatian atas prestasi kerja siswa yang terbaik

d. Merefleksikan kesanggupan mengambil resiko dan melakukan eksperimentasi

e. Meningkatkan efektivitas proses pengajaran

f. Bertukar informasi dengan orang tua /wali dan guru lain

g. Membina dan mempercepat pertumbuhan konsep diri positif pada siswa 
h. Meningkatkan kemampuan melakukan refleksi diri

i. Membantu siswa dalam merumuskan tujuan

Penilaian portofolio pada dasarnya menilai karya-karya siswa secara individu pada satu periode untuk suatu mata pelajaran. Akhir suatu periode hasil karya tersebut dikumpulkan dan dinilai oleh guru dan peserta didik. Berdasarkan informasi perkembangan tersebut, guru dan peserta didik sendiri dapat menilai perkembangan kemampuan peserta didik dan terus melakukan perbaikan. Dengan demikian, portofolio dapat memperhatikan perkembangan kemajuan belajar peserta didik melalui kayanya, antara lain: karangan, puisi, surat, komposisi, musik.

Portofolio tidak hanya merupakan tempat penyimpanan hasil pekerjaan siswa, tetapi juga merupakan sumber informasi untuk guru dan siswa. Portofolio memberikan bahan tindak lanjut dari suatu pekerjaan yang telah dilakukan siswa sehingga guru dan siswa berkesempatan untuk mengembangkan kemampuannya. Portofolio dapat pula berfungsi sebagai alat untuk melihat (a) perkembangan tanggung jawab siswa dalam belajar, (b) perluasan dimensi belajar, (c) pembaharuan kembali proses belajar-mengajar, dan (d) penekanan pada pengembangan pandangan siswa dalam belajar.

\section{Prinsip Penilaian Portofolio}

Penilaian portofolio melibatkan banyak orang. Guru bukan satu-satunya penilai. Penilaian akhir portofolio merupakan kolaborasi dari penilaian guru, siswa pemilik portofolio, siswa sejawat, adik/kakak kelas, orang tua, akademisi dari lembaga lain (seolah/PT/lembaga kursus), dan atau pihak lain yang memiliki pengetahuan dan kewenangan mengenai hasil portofolio yang akan dinilai. Mengingat banyaknya pihak yang terlibat dalam penilaian portofolio, pelaksanaannya membutuhkan sejumlah prinsip utama yang menjadi ramburambu dalam penilaian.

Penilaian portofolio beranjak dari lima prinsip utama, yaitu saling mempercayai, kerahasiaan, milik bersama, kepuasan, dan kesesuaian. Kelima 
prinsip ini terkait satu dengan yang lain dan merupakan satu kesatuan yang tak terpisahkan.

Prinsip saling mempercayai dibutuhkan karena penilaian portofolio melibatkan sejumlah orang. Rasa saling percaya memunculkan keabsahan penilaian. Unsur sentimen atau niat menjatuhkan orang lain dijauhkan dari penilaian portofolio. Sepanjang kepercayaan tidak ditumbuhkan, keobjektifan penilaian tidak akan pernah diperoleh. Rasa curiga merupakan penyakit berkepanjangan yang menodai penilaian. Untuk itu, tumbuhkan terus rasa saling percaya.

Prinsip kerahasiaan dibutuhkan karena penilaian portofolio memberi peluang untuk mengungkap aspek pribadi yang dimiliki seseorang. Setiap manusia memiliki cela, baik penilai maupun orang yang dinilai. Dalam rangka tetap menempatkan seseorang dalam posisi positif dalam kedudukan bermasyarakat, kerahasiaan amat dibutuhkan. Rasa bersalah dan aib yang dimiliki seseorang jika ketahuan secara umum akan menyebabkan tersisih dalam kelompoknya. Untuk itu, prinsip kerahasiaan amat dibutuhkan dalam penilaian portofolio.

Prinsip milik bersama dibutuhkan dalam penilaian portofolio bertujuan utama mengembangkan kualitas peserta didik. Jika output yang dihasilkan berupa produk, tilikan dari berbagai segi untuk menyempurnakan produk itu akan menghasilkan produk akhir yang lebih baik. Prinsip milik bersama dimaksudkan agar semua pihak secara bersama-sama mengupayakan pengembangan kualitas hasil akhir.

Prinsip kepuasan dalam penilaian portofolio merupakan sukma dari tersebut. Tiga unsur yang perlu menikmati kepuasan itu, yaitu siswa, penilai, dan masyarakat luar. Kepuasan dalam penilaian portofolio meliputi dua hal yakni kepuasan proses dan kepuasan hasil. Kepuasan akan memberikan dorongan yang kuat untuk mencapai prestasi gemilang pada aktivitas berikutnya.

Prinsip kesesuaian meliputi tiga hal, yaitu sesuai dengan tujuan yang akan dicapai, sesuai dengan perkembangan psikologis siswa (usia, emosional, dan 
intelektual), sesuai dengan kebutuhan nyata sehari-hari. Prinsip kesesuaian terkait erat dengan kemasadepanan siswa.

\section{Manfaat Penilaian Portofolio}

Berikut ini sejumlah manfaat yang dapat diperoleh dalam penerapan penilaian portofolio.

a. Guru dapat menilai perkembangan dan kemajuan siswa

b. Guru dan wali murid dapat berkomunikasi tentang pekerjaan siswanya.

c. Siswa menjadi partner dengan gurunya dalam hal proses penilaian

d. Siswa dapat merefleksikan dirinya sesuai bakat dan kemampuannya

e. Penilaian tersebut mampu menilai secara obyektif terhadap individu

f. Meningkatkan interaksi antara siswa dengan guru untuk mencapai suatu tujuan

g. Meningkatkan motivasi siswa untuk belajar, kebanggaan (pride), kepemilikan (ownership), dan menumbuhkan kepercayaan diri (self convidence)

h. Mencapai ketuntasan belajar dan bukan sekedar tuntas materi

i. Guru bersama pengawas dapat mengevaluasi program pengajaran

j. Meningkatkan profesionalisme guru

\section{Bahan Penilaian Portofolio}

Data penilaian portofolio peserta didik didasarkan dari hasil kumpulan informasi yang telah dilakukan oleh peserta didik selama pembelajaran berlangsung. Komponen penilaian portofolio meliputi: (1) catatan guru, (2) hasil pekerjaan peserta didik, dan (3) profil perkembangan peserta didik. Hasil catatan guru mampu memberi penilaian terhadap sikap peserta didik dalam melakukan kegiatan portofolio. Hasil pekerjaan peserta didik mampu memberi skor berdasarkan kriteria (1) rangkuman isi portofolio, (2) dokumentasi/data dalam folder, (3) perkembangan dokumen, (4) ringkasan setiap dokumen, (5) presentasi dan (6) penampilan.

Hasil profil perkembangan peserta didik mampu memberi skor berdasarkan gambaran perkembangan pencapaian kompetensi peserta didik pada selang waktu 
tertentu. Ketiga komponen ini dijadikan suatu informasi tentang tingkat kemajuan atau penguasaan kompetensi peserta didik sebagai hasil dari proses pembelajaran. Berdasarkan ketiga komponen penilaian tersebut, guru menilai peserta didik dengan menggunakan acuan patokan kriteria yang artinya apakah peserta didik telah mencapai kompetensi yang diharapkan dalam bentuk persentase (\%) pencapaian atau dengan menggunakan skala 0-10 atau 0-100.

Penskoran dilakukan berdasarkan kegiatan unjuk kerja, dengan ramburambu atau kriteria penskoran portofolio yang telah ditetapkan. Skor pencapaian peserta didik dapat diubah ke dalam skor yang berskala 0-10 atau 0-100 dengan patokan jumlah skor pencapaian dibagi skor maksimum yang dapat dicapai, di kali dengan 10 atau 100. Dengan demikian akan diperoleh skor peserta didik berdasarkan portofolio masing-masing.Bahan penilaian portofolio meliputi:
a. Penghargaan tertulis
b. Penghargaan lisan yang tertulis
c. Hasil kerja biasa dan hasil pelaksanaan tugas-tugas oleh siswa
d. Daftar ringkasan hasil pekerjaan
e. Catatan sebagai peserta dalam suatu kerja kelompok
f. Contoh hasil pekerjaan
g. Laporan hasil pekerjaan
h. Catatan/laporan dari pihak lain yang relevan
i. Kopi absen/ daftar kehadiran
j. Presentasi dari tugas-tugas yang selesai dikerjakan
k. Catatan-catatan negatif (misalnya: peringatan) tentang siswa

\section{Bentuk-Bentuk Hasil Portofolio}

Portofoliodapatdikembangkandalamberbagaibentuk.Bentuk-bentuk penilaian portofolio meliputihalberikut.
a. Catatan anekdot
b. Tulisan refleksi
c. Review
d. Laporan 
e. Rekaman video tapes

f. Photo/gambar

g. Cuplikan tulisan

h. Grafik dan chart

i. Hasil print out komputer

j. Diagram

k. Uisi

1. Catatan diskusi/kegiatan di rumah

m. Rekaman sesuau/audiotapes

n. Draft

o. Ilustrasi

p. Karya berupa benda

q. Model/maket

r. Kliping

S. Diagram

t. Lagu

\section{Pedoman dan Karakteristik Pengembangan Portofolio}

Hal-hal yang perlu diperhatikan dan dijadikan pedoman dalam penggunaan penilaian portofolio di sekolah antara lain:

a. Karya Siswa Adalah Benar-Benar Karya Peserta Didik Itu Sendiri Guru melakukan penelitian atas hasil karya peserta didik yang dijadikan bahan penilaian portofolio agar karya tersebut merupakan hasil karya yang dibuat oleh peserta didik itu sediri.

b. Saling Percaya Antara Guru dan Peserta Didik

Dalam proses penilaian guru dan peserta didik harus memiliki rasa saling percaya, saling memerlukan dan saling membantu sehingga terjadi proses pendidikan berlangsung dengan baik.

c. Kerahasiaan Bersama Antara Guru dan Peserta Didik

Kerahasiaan hasil pengumpulan informasi perkembangan peserta didik perlu dijaga dengan baik dan tidak disampaikankepadapihak- 
pihakyangtidakberkepentingan sehingga memberi dampak negatif proses pendidikan.

d. Milik Bersama (Joint ownership) Antara Peserta Didik dan Guru

Guru dan peserta didik perlu mempunyai rasa memiliki berkas portofolio sehingga peserta didik akan merasa memiliki karya yang dikumpulkan dan akhirnya akan berupaya terus meningkatkan kemampuannya

e. Kepuasan

Hasil kerja portofolio sebaiknya berisi keterangan dan atau bukti yang memberikan dorongan peserta didik untuk lebih meningkatkan diri

f. Kesesuaian

Hasil kerja yang dikumpulkan adalah hasil kerja yang sesuai dengan kompetensi yang tercantum dalam kurikulum

g. Penilaian Proses dan Hasil

Penilaian portofolio menerapkan prinsip proses dan hasil. Proses belajar yang dinilai misalnya diperoleh dari catatan guru tentang kinerja dan karya peserta didik

h. Penilaian dan Pembelajaran

Penilaian portofolio merupakan hal yang tidak terpisahkan dari proses pembelajaran. Manfaat utama penilaian ini sebagai diagnostik yang sangat berarti bagi guru untuk melihat kelebihan dan kekurangan peserta didik

\section{Keunggulan Dan Kelemahan Penilaian Portofolio}

Penilaian portofolio memiliki keunggulan dan tentunya kelemahan dalam pelaksanaannya di kelas. Keunggulan yang dari penggunaan penilaian portofolio dapat dilihat dari kondisi-kondisi di bawah ini sebagai berikut:

a. Perubahan Paradigma Penilaian

Perubahan paradigma dari membandingkan kedudukan kemampuan peserta didik menjadi pengembangan kemampuan peserta didik melalui umpan balik dan refleksi diri. Penilaian portofolio dapat menolong guru melakukan dan mengevaluasi kemampuan dan peserta disidik sesuai dengan harapan tanpa mengurangi kreativitas peserta didik di kelas. Penilaian portofolio juga dapat 
menolong peserta didik untuk bertanggung jawab terhadap apa yang mereka kerjakan di kelas dan meningkatkan peran serta mereka dalam kegiatan pembelajaran.

b. Akuntabilitas

Penilaian portofolio menekankan pada keadaan yang dapat dipertanggungjawabkan (akuntability). Hal ini dapat dilihat dari adanya kerja sama antara guru, siswa dan orang tua. Jadi bukan semata-mata guru yang memberikan penilaian, tetapi atas sepengetahuan siswa dan orang tua.

c. Peserta Didik Sebagai Individu yang Peran Aktif Peserta Didik

Ciri khas dari penilaian portofolio adalah memungkinkan guru untuk melihat peserta didik sebagai individu yang masing-masing memiliki karakteristik, kebutuhan, dan kelebihan tersendiri. Ini sangat berguna manakala program evaluasi sangat fleksibel dan lebih menekankan pada tujuan individual sehingga memungkinkan peran aktif dalam proses penilaian, dan memberikan kesempatan untuk meningkatkan kemampuan mereka

d. Identifikasi

Penilaian portofolio dapat mengklasifikasi dan mengidentifikasi program pengajaran dan memungkinkan untuk mendokumentasikan "pemikiran” di samping pengembangan program, sehingga kriteria portofolio akan berpengaruh terhadap penentuan tujuan pembelajaran (indikator pencapaian hasil belajar)

e. Keterlibatan Orang Tua dan Masyarakat

Penilaian portofolio melibatkan orang tua da masyarakat untuk berperan serta dalam melibatkan pencapaian kemampuan peserta didik yang berkaitan dengan konteks kurikulum dibandingkan dengan hanya melihat angka-angka tes yang selama ini dihasilkan

f. Penilaian Diri

Portofolio memungkinkan peserta didik melakukan penilaian diri (self assessment), refleksi, dan pemikiran yang kritis (critical thinking).penilaian diri adalah penilaian yang digunakan oleh peserta didik untuk menilai evidence mereka. Peserta didik harus memiliki kemampuan (skill), 
pengetahuan (knowledge), dan keyakinan diri (confidence) untuk mengevaluasi proses yang mereka sedang kerjakan dan pengembangan hasil kerjanya, ketika mereka belajar sebagai pelajar yang mandiri. Penelitian diri berguna untuk melihat keterlibatan peserta didik sepenuhnya dalam proses pembelajaran yang sedang berlangsung

g. Penilaian yang Fleksibel

Penilaian portofolio memungkinkan penilaian yang fleksibel yang bergantung kepada indikator pencapaian hasil belajar yang telah ditentukan.

h. Tanggung Jawab Bersama

Penilaian portofolio memungkinkan guru dan peserta didik secara bersamasama bertanggung jawab untuk merancang proses pembelajaran dan untuk mengevaluasi kemajuan belajar yang sesuai dengan tujuan pembelajaran.

i. Keadilan

Portofolio adalah salah satu alat penilaian yang ideal untuk kelas yang heterogen yang sangat terbuka bagi guru untuk menggambarkan kelebihan dan kekurangan peserta didik da membantu perkembangan mereka

j. Kriteria Penilaian

Hasil pekerjaan peserta didik akan dinilai berdasarkan penilaian yang relevan dengan penampilan mereka (misal dengan skala rating = rating scale). Peserta didik yang kurang akan tetap mendapat penghargaan (credit), sedangkan pencapaian keberhasilan yang optimal menjadi tujuan dari penilaian portofolio ini.

Dari keberhasilan yang telah diuraikan di atas, terdapat juga beberapa kelemahan yang dialami saat dilaksanakannya penilaian portofolio antara lainsebagaiberikut.

a. Waktu Ekstra

Penilaian portofolio memerlukan kerja ekstra dibandingkan dengan penilaian lain yang biasa guru lakukan. Tetapi usaha guru yang menggunakan penilaian portofolio akan sangat dihargai dan terutama dikenang baik oleh peserta didik. Sebab melalui penilaian portofolio peserta didik dapat meningkatkan motivasi, 
partisipasi aktif dalam proses pembelajaran, bahkan meningkatkan kemampuan mereka

b. Reliabilitas

Penilaian portofolio nampak kurang reliabel dan kurang fair dibandingkan dengan penilaian lain yang menggunakan angka seperti ulangan harian, ulangan umum, maupun ujian akhir nasional yang menggunakan tes. Penilaian yang dilakukan sendiri oleh peserta didik (self assessment) maupun oleh kelompok peserta didik agak kurang reliabel oleh karena itu latihan penilaian yang dilakukan oleh peserta didik maupun kelompok peserta didik sangat diperlukan. Dengan adanya latihan yang terus menerus, terutama lagi apalagi kriteria yang disajikan sangat jelas dan mudah dipahami. Peserta didik akan berlatih menjadi penilai bagi pekerjaannya sendiri.

c. Pencapaian akhir

Guru memiliki kecenderungan memperhatikan hanya untuk pencapaian akhir. Jika hal ini terjadi, berarti proses penilaian portofolio tidak mendapatkan perhatian sewajarnya.

d. Top-Down

Guru dan peserta didik biasanya terjebak dalam suasananya hubungan topdown, yaitu guru menganggap tahu segalanya dan peserta didik selalu dianggap sebagai obyek yang harus dididik dan diberi tahu. Dengan demikian proses pembelajaran menjadi satu arah. Apalagi kondisi ini terwujud, maka inisiatif dan kreativitas peserta didik yang menjadi ciri khas portofolio akan hilang.

e. Skeptisme

Masyarakat, khususnya orang tua peserta didik selama ini hanya mengenal keberhasilan anaknya hanya pada angka-angka hasil tes akhir (test scores), peringkat dan hal-hal yang bersifat kuantitatif. Sebaliknya, portofolio pada hakikatnya tidak mengenal angka-angka yang dimaksud. Akibatnya terkadang orang tua bersikap skeptis dan lebih percaya pada tes dari pada penilaian portofolio. Untuk mengatasi hal tersebut, format penilaian dapat menggunakan 
kriteria penilaian yang bervariasi, mulai dari tidak menggunakan angka sampai dengan menggunakan angka.

f. Hal yang Baru

Penilaian portofolio adalah sesuatu yang baru dalam dunia pendidikan di Indonesia. Oleh karena itu bukan tidak mungkin kebanyakan guru kurang mengenal penilaian portofolio, mereka lebih mengenal bentuk penilaian yang biasa dilakukan.

g. Penerapan di Sekolah

Penilaian portofolio terkadang sulit diterapkan di sekolah yang lebih mengenal perbandingan peserta didik melalui skor tes, peringkat dan yang lebih sering menggunakan tes yang sudah baku seperti Ujian Nasional

h. Format Penilaian yang Lengkap dan Detail

Penyediaan format yang digunakan secara lengkap dan detail, dapat juga menjebak. Peserta didik akan terjerumus ke dalam suasananya yang kaku dan mematikan, yang akhirnya akan mematikan inisiatif dan kreativitas.

i. Tempat Penyimpanan

Penilaian portofolio memerlukan tempat penyimpanan yang memadai, apalagi bila jumlah peserta didik cukup banyak. Oleh karena itu, guru perlu mewaspadai hal tersebut.

\section{PENUTUP}

Secara umum portofolio merupakan kumpulan dokumen seseorang , kelompok, lembaga, organisasi, perusahaan atau sejenisnya yang bertujuan untuk mendokumentasikan perkembangan suatu proses dalam mencapai tujuan yang telah ditetapkan. Portofolio dapat digunakan untuk mendokumentasikan perkembangan siswa. Karena menyadari proses belajar sangat penting untuk keberhasilan hidup, portofolio dapat digunakan oleh siswa untuk melihat kemajuan mereka sendiri terutama dalam hal perkembangan, sikap keterampilan dan ekspresinya terhadap sesuatu.

Pembelajaran berbasis portofolio memposisikan siswa sebagai titik sentralnya (student oriented). Dalam proses pembelajaran siswa harus dimotivasi 
untuk mau dan mampu melakukan sesuatu untuk memperkaya pengalaman bekerjanya dengan lebih mengintensifkan interaksi dengan lingkungannya. Dengan interaksi ini diharapkan mampu membangun pemahaman terhadap dunia sekitar, kepercayaan diri dan kepribadian siswa yang paham akan keanekaragaman yang ada gilirannya dapat tumbuh sikap positif dan perilaku toleran terhadap kebinekaan dan perbedaan pola kehidupan. Dengan demikian pembelajaran portofolio merupakan model pembelajaran partisipatorik, yaitu belajar sambil menjalankan (learning by doing) dengan proses sebagai berikut (1) mengidentifikasi masalah; (2) memilih masalah sebagai bahan kajian kelas; (3) mengumpulkan informasi masalah yang akan dikaji; (4) mengembangkan portofolio kelas; (5) menyajikan portofolio; dan (6) merefleksikan pengalaman belajar.

Model portofolio assessment cocok digunakan untuk mata pelajaran yang bersifat menuntut output pembelajaran siswa dari segi pengetahuan, keterampilan dan sikap. Penilaian ini berupa penilaian terhadap sekumpulan karya peserta didik yang tersusun secara sistematis dan terorganisir yang diambil selama proses pembelajaran dalam kurun waktu tertentu. Olehsebabitu guru sebaiknyamenggunakanpenilaianini agar mutupembelajaransemakinmeningkat.

\section{DAFTAR PUSTAKA}

Budimansyah, Dasim. (2002). Model Pembelajaran Dan Penilaian Portofolio. Bandung: PT Ganesindo

Djahiri, A.K. (2000). Model Pembelajaran Portofolio Terpadu Dan Utuh. Bandung: PPKnH UPI dan CICED

Gronlund, N. E., dan Linn, R. L. (1990). Measurement And Evaluation In Teaching. New York: Allyn \& Bacon- A Simon \& Schuster Company.

Tsauri, sufyan (2009). Penilaian Portofolio Online. [Online]. Tersedia di http://tsauri28.myhaley.com/blog/penilaian-portofolio-online/. 19 Maret 2011

Uzer Usman, Mohd. (2002). Menjadi Guru Profesional. Yogyakarta: PT Remaja Rosdakarya

Winataputra, U.S. (1999. Rancangan Perintisan Model Pembelajaran Portofolio Di Delapan Propinsi. Bandung: UT dan CICED 


\section{BIODATA}

Realin SetiamihardjaadalahdosenUniversitasPendidikan Indonesia KampusCibiru yang membidangimatakuliahevaluasipendidikan sekolahdasardanpendidikananakusiadini. 